\begin{tabular}{c} 
Volume and Issues Obtainable at Center for Sustainability Research and Consultancy \\
Journal of Business and Social Review in Emerging Economies \\
ISSN: 2519-089X (E): 2519-0326 \\
Volume 6: No. 1, March 2020 \\
CSRᄃ \\
Journal homepage: www.publishing.globalcsrc.org/jbsee \\
\hline
\end{tabular}

\title{
A Study on the Effect of Emerging Technology on Students' Academic Achievements at Secondary Level
}

\author{
${ }^{1}$ Shabnam Bibi, ${ }^{2}$ Muhammad Hameed Nawaz \\ ${ }^{1}$ Ph.D (Education), University of Lahore, Lahore, Pakistan. shabnirehman@ gmail.com \\ ${ }^{2}$ Associate Professor Dept. Of Education, University of Lahore, Pakistan. drmhrpk@yahoo.com
}

\begin{tabular}{l} 
ARTICLE DETAILS \\
\hline History \\
Revised format: February 2020 \\
Available Online: March 2020
\end{tabular}

Keywords

Instructional Technology,

experiment, secondary level

student

JEL Classification:

N7, A20

\begin{abstract}
Use of emerging technology provided an easy access opportunity to the learners in this world they can find out a fruitful and healthy environment for learning in this fast technology world, Therefore, the aim of the present study was "a study on the effect of emerging technology on students' academic achievements at secondary level". The sampling population of the present study is all students of grade 10 who are studying in public high school in Punjab. Use of emerging technology and its experiment was delimited to Biology students of class 10th in Govt Girls High School No1 Fateh Jang (Attock) sessions 2016-17 and its experiments was delimited to four chapters of Biology textbook. This study sought to discover that learning through emerging technology improved student academic achievement. Two different methods of instruction were employed for this research study. The first method of instruction was the traditional lecture and whiteboard method. The second method of instruction was the use of technological instruction. Students of 10th class in subject Biology were studied. Two groups controlled and experimental was selected on the basis of pre test to equate the knowledge level for experiment. For item analysis, researcher used SPSS, Mean. Overall the achievements of students were satisfactory. After analysis of the data conclusions were drawn that there is major difference between the students of experimental post and control post. The mean score of experimental post students is greater than control post. It is recommended that Teachers should use Emerging Technology based teaching aids like computer animations etc. to develop student's interest in the subject for maximum teaching learning out-comes.
\end{abstract}

(C) 2020 The authors, under a Creative Commons Attribution-

NonCommercial 4.0

Corresponding author's email address: shabnirehman@ gmail.com

Recommended citation: Bibi, S., \& Nawaz, M.H. (2020) A Study on the Effect of Emerging Technology on Students' Academic Achievements at Secondary Level. Journal of Business and Social Review in Emerging Economies, 6(1), 365-378

DOI: $10.26710 /$ jbsee.v6i1.1088 


\section{Introduction}

For the progress and prosperity of human education is the most crucial element. Education is a discipline for the adventure of life. It implies the training of a person in a certain skill or knowledge so it prepares an individual for a vocation and he can develop himself in a sound personality with the help of education. According to Iqbal (2002, p.1), Education is the backbone for the development and success of any country. Oxford Advanced Learners Dictionary of Current English (2000, p.369) defines education as "A Process of training and instruction, especially of children and young people in schools, colleges, etc which is designed to give knowledge and develop skills".

We were using old curriculum in science that was not only latest and healthy for the students but also was irrelevant with desired experiments, that material couldn't make clear concept for experiments and couldn't provide the place for further opportunity. Unluckily in our country we have traditional learning style teachers use notes and their curriculum books and teach the students. They give typically concept and old knowledge that was provided in books only.

Karehka (2012) stated that for the charming result we should add technology based learning in our daily lives and learning. Only technology is the thing that will bring change and mold the mind of learners for doing something new and latest. In $21^{\text {st }}$ century only multi tasked learners can survive and get in the race of doing good and develop new technology. For example, let's talk about environmental issues. They did not create all of these environmental problems; this and the fault of previous generations. Again, we expect these students to address these issues. The question arises here: are we preparing these students to solve problems. Pakistan, which sits in our classes today, has a future. What are we doing for them? Now or never. We need to take serious steps to fill the gap, and schools can prepare students for their future careers by using a mixed learning model to help them develop 21 st century core skills.

This research promotes biological techniques. In view of its importance, advanced countries of the world give extraordinary concentration to the study of biology and to meet the challenges of up to date society it is essential for the teachers and subject specialists to adopt new techniques of teaching. Biology is neither static nor dull but a dynamic subject. It can be made lively and exciting by effective teaching method; therefore, it is very important, that a research may be conducted to find out effective method of teaching biology at secondary level. Research proves that Teaching of Biology with the help of emerging technology is more effective to increase cognitive learning of students and its effects on students' achievement. Emerging technology based learning is flattering more and more frequent and it has been significant particularly at complicated subjects in science for over two decades. In the present age by using emerging technology researchers studying on Biology, Medical Chemistry, Molecular Chemistry, and Accounting Molecular Orbital are administered to easiness assembling and dispensation data and increase speed (Uzma, 2014).

The fundamental aim of this study will be to investigate the sound effects of the emerging technology based teaching and learning Biology students. Materials such as videos, slides, CD's, sounds and animations in the Biology teaching course makes it probable to have an interactive and energetic lesson and at other hand, the presentations containing ant topic by means of rich visual materials enhance the achievements and as well fruitful for the learners. It is stated that the use of instructional technology based teaching has positive effects on the learners' achievements.

\section{Statement of the Problem}

An attempt was made to find the level of student achievement by a specific demonstrative method under the heading of "A study on the effects of the use of emerging technology on students' academic achievements at secondary level in Biology".

\section{Objectives of the Study}

The following were the objectives of the study:

1. To specify the role of emerging technology in education. 
2. To evaluate the effect of the use of emerging technology on students' academic achievement.

3. To make recommendations for the use of effective method for teaching.

\section{Population}

The purpose of this experimental research study was to examine the effects of the use of emerging technology on students' academic achievements at secondary level in Biology by classroom teachers. The target population of the study was $10^{\text {th }}$ grade girl students studying in all the rural and urban govt girls' secondary schools of District Attock under the administration of the Punjab government in Pakistan.

\section{Sample}

Two groups controlled and experimental was selected on the basis of pre test to equate the knowledge level for experiment. The 60 girl students of grade $10^{\text {th }}$ were the sample of the study studying in Govt. Girls High School No 1 Fateh Jhang, comprising 30 girls both groups the experimental group and control group.

\section{Research Methodology}

This study wanted to find out the use of emerging technology to deliver instruction and improved the students' academic achievement. There were two different methods of teaching were used for this research study. The traditional lecture and whiteboard method was used as first method of teaching. The second method of instruction was the use of technological instruction. Research is experimental in nature and methodology includes the following steps:

\section{Tool of Research}

Two instruments were used to conduct the present study:

i. The pre-test

ii. The post-test

\section{What is Emerging Technology?}

Definition: Emerging technology is the use of just what it sounds lie, via any system, and it's all accessories like; small and temporary memories, videos, satellites, modem, phone meetings and means to prop up teaching learning system. The aim of emerging technology is to deliver instructions by practically techniques for fruitful learning and it doesn't mean that use of any media is necessary; it is just to aid the instructions in validated procedures and design.

There are some aspects of emerging technology:

- Dynamic styles to manipulative instruction.

- The efficient use of group work.

- The assessment of designs.

- Process of designing the instruction.

- Application of learning theories.

- A collection of materials and tools to design and put into practice (design).

- The improvement in knowledge and conveying of instruction.

It is elaborated by Association of Educational Communications and Technology (AECT) that it is used to cope with the processes of learning approach and instructions they also stated that Emerging Technology referred as a helping hand of education. Instructional technologies also have some other systems that are able to use in the improvement of capabilities of the learners".

\section{Selection of the Technology}

Every latest technology is not fruitful and the acceptance of technology as it may be not the resource of desirable goals oriented. Teachers and instructor are the responsible that they search for a latest 
technology for their classroom and asks to know how it suitable for learning objectives and goals not for some other means like some latest technology is received for education but after that it is a teacher attempts to adjust it in the classroom. As this example, Cynthia (2008) stated a teacher told her that "all our students are getting laptops and now we are desperate to figure out something for them to do on them." Use of technology by instructor in classroom, the instructor must have fully command in operating the emerging technology. So many studies conducted to show the results of student's improvement, using by computer assisted program and activities, but they failed to help the educators to understand how technologies might, or might not, helps learners to support cognitive learning and the kind of analysis by students that is preferred Kulik (2009).

To achieve the desired outcomes to instructors, they should adopt an effectual, ground-breaking and healthy technologies, in a broader sense; it is an improvement in the environment of education system with the use of latest instructional technology have to get into account immediately modifications in time and space limitations, curriculum development, communication, administration and a array of additional organizational and social features Margaret, Katherine and Fred (2000).

In the selection which technology could be the most cooperative and helping hand in accomplishing personally and department goals, Cynthia (2008) created a framework for a different process to facilitate the instructors they can operate it to achieve the goals oriented accomplishment of knowledge instructional technologies as well as the purpose of the selection her four steps process includes:

1. Strategy making,

2. Strategic plan design and preparation,

3. Strategic analysis, and

4. Strategic plan implementation.

At the stage of the planning and its preparation the use of emerging technology and before moving on the stage of implementation, Andrew Sackville established a list of lessons and advice:

1. Do search for replacement the ideas don't try to put a ceiling searching to your individual discipline or employment sector. Just assume external the box use up your time thinking.

2. Never skip the chance to review accept innovations simply for the reason that you don't feel like to make a fool of yourself.

3. To modify your idea, try to search out as much as you can and inquire a broad question that must relate to education. How can it bone up the learning of students? How will I able to make my colleagues understand and agreed for my suggestions and idea?

4. Be doubtful! Do the groundwork in time and raise the questions, where does the improvement come from? And, who will be beneficial by using this?

5. Recognize possible modification representatives, early adopters work with them.

6. Keep away from sharing people accurately what to do and how to do it. As an alternative, explain the end results you are looking for, and inquire them to produce their own ideas for how to approach it.

7. For the initiates and modern teaching strategy do make out possible consequences. How much it will be accessible for all learners? If we adopted this teaching method or this technology will there few disadvantaged?

8. Need to get ready to modify the mind, because you calculate development and improvement and innovation, be ready to give up it if required.

9. Be heartening researching, at the same time as faced a tough challenge, make inquiries others to recommend suggestions and changes so that it could be victorious whenever existing practice fails, permit them to find fresh things.

10. Defy the personnel elements to be further innovative by motivating them to raise the question how things are done Ryan (2010, p. 2, 3).

\section{Traditional Classroom Instruction and Emerging Technology Instruction}

According to Emma (2010) traditional learning system students are consider as passive receptors of 
information and without deliberation of the need to actively participate in the learning process. Traditional learning approach be generally based surrounded by traditional learning surroundings for instance laboratories and classes of lectures. The academies, at the same time as the teachers, are the answerable for the whole process of education like as manipulative the core curriculum, background of the activities and organize the evaluation procedure, by means of education in the direction of the after that exam. The traditional learning approach just followed in pedagogic level, deliver the lecture traditionally and memorizing and note the information when 0they get the point (MacLellan and Soden 2004, p. 254).

In this culture and this age, the approach of emerging technology is totally new and goal oriented approach, to the philosophy fundamental the conventional method of learning. Emerging technology based learning as its nature permits the learners to learn by their selves and go through with related information and give a shape to his/her personality and also take part to build their educational process fruitful and healthy. As means of description, learning experience is not a passive one in learning through emerging technology, it is just based on the assumption that "passivity of learners has no matter in the improvement of learning and even not to support the learning' it is accurately 'a learning that is full of energy' which lends a hand in learning that student learn in freely atmosphere (MacHemer and Crawford, 2007, p. 11). Emerging technology based learning is energetic motivations for learning to the learners, to develop the ability of cooperates and help each other not to competition in students in learning process. As the part of this approach the students are given the opportunity to match up to their ideas in the company of their examiners and their teachers, at the same time as they taking part to develop their curriculum in a significantly frame. Within this framework, the academic or instructors are not the source of knowledge they play the role as facilitator and motivate the learners to ask the questions and show interest. Therefore, in this approach the role of the teacher has been twisted, from being entrusted with the 'communication of knowledge to supporting and guiding self-regulated student learning' (Van, et al, 2005, p.447). Whole knowledge is created the same as individuals and to build the sense of their experimental worlds (MacLellan 2004, p. 254). Sometimes emerging technological based learning modifies the rationale of getting knowledge, it creates the atmosphere in which learners can develop the inner qualities and transversal competences and create the critical thinking for knowledge.

\section{Benefits of Emeging Technologies}

Emerging technologies in classroom are much beneficial. It is impossible to describe all benefits but some major benefits are according to Yun-Jo and Bosede Aworuwa (2010):

\section{$>$ Collaboration and Interaction}

Having emerging technologies in education system, facilitate and create group of people, create interact and communicate between the instructor, students, and further people, and also source to promote collaboration and resource sharing. Furthermore, it is a foundation of trim down the distance between instructor and students they go through by fresh and latest ways of collaboration and equally students and teachers make out learning as a more social process.

\section{$>$ Knowledge creation}

Emerging technologies facilitate the students to "turn out to be creators of knowledge as emerging technologies bestow students "the opportunity to create content themselves instead of just listening to lectures," This backup energetic and student centered learning where learners acquire learning responsibility. Emerging technologies create a facilitating atmosphere for instructors and learners.

\section{$>$ Proficient of writing skill}

The used of emerging technologies lend a hand for students to turn out to be extra talented in editing and in the functions of technology. The teachers are facilitating by emerging technologies to recognize a modest for their students, and inspire the learners as per their wish and necessitate.

\section{Barriers To Using Emerging Technologies In Teaching}

Preparation of educator and appropriate proficient development is barrier to successful use of emerging technology in the classroom. Another issue is lack of proper access to restrictive the use of emerging 
technology in the classroom. Effectiveness of emerging technology in the classroom developed by proper access and use so the lacking of suitable approach; students possibly will go down at the back. The educational centers those didn't have sufficient access to emerging technology will be unsuccessful to in research and practice, accessibility to emerging technology is essential. In educational institute having sufficient broadband access is tremendously important, Broadband access is defined as "The more powerful the capability to transmit data, the richer the online experience" (Web-based Commission 2000, 22). At the same time as having sufficient access to emerging technology at education centers is very important, so need for having access not only at home but also at working places; everywhere on earth learning opportunities can be create. In the past a small number of years the learners who have they have emerging technology at home has improve their grades than before even rural areas are infectious up to those who are from urban areas. On the other hand, the students who don't contain emerging technology at their home, it is compulsory for schools of that area they must provide the access and facility in the classroom. "School computers are the only link to the Internet for many socioeconomically disadvantaged and minority children" (Swain and Pearson 2003).

Web-based Commission $(2000,39)$ elaborates that "teachers are the key to effective use of web-based tools and applications, but first they must become skilled at using them." Professional progress is the critical element intended for effectual use of emerging technology in the classroom. The educational community ought to move toward the implementation of emerging technology in the classroom in a manner comparable to that employed by the business sector. According to the CEO Forum on Education and Technology $(2001,9)$, "studies continue to demonstrate that educators' access to professional development remains the single most critical factor as to whether or not technology improves student achievement." Instructors need having time to be present at professional development classes of far above the ground quality. It is most significant to "provide opportunities for professional development that meets teachers learning needs in 21st century areas, such as project management, information literacy, and interdisciplinary instructional design" (Boss and Krauss 2007). In order to increase the effectiveness of emerging technologies and enhance classroom learning, education policymakers need to incorporate education reform as part of an overall technology improvement program and study its development and outcomes to improve efforts over time. should continue to learn. Despite the positive impact of evolving technologies on improving the learning environment, there are barriers that limit the effectiveness of technology in the classroom. Technology evolving in the classroom is just one part of the puzzle, it needs to be effective and impactful, and school reform needs to be at all levels; in the classroom and at school (Attewell, 2001).

\section{Impact of Emerging Technology on Academic Performance}

Emerging technology is capable of perk up what the secondary level students learn focuses on courses that aide in secondary level students' comprehension of central part of subjects like Biology, Physics, Chemistry, Math, and reading, through presenting subject material in extra with no trouble understood formats. Emerging technology based applications is capable of applied in science classrooms and labs. The students obtain higher test scores and are able to greater understanding of the subject material. Roschelle, et al. (2000, p. 86) declare that "emerging technology based applications using visualization; modeling and simulation contain established authoritative tools for teaching scientific concepts." At the time when authentic emerging technology applications will be use in the classroom, such Thinker Tools improve well with the understanding of subject material in the grades level of secondary level students. The secondary school students used this emerging technology assisted learning program had enhanced the knowledge to appreciate and give in details concepts that were typically teach well above their grade level.

Emerging technologies provide the source to go through complete books; and students of this grade feel satisfaction in examining small sections of text and material (Ringstaff and Kelley, 2002, 6). Using by emerging technology the students of this level able to access to online libraries and so many resources 
from there they can get information about the topic of their subject biology. "Students of secondary level who used and practice with emerging technology to contribute to already learned skill sets, improved their academic performance on standardized tests" (Attewell, 2001). Grace, (2007) the Center for Applied Research in Educational Technology (CARET) states that the development of secondary level student's performance in education by emerging technology there are six key ways:

I. Integrated with curriculum content is most effective.

II. It enhances the performance of students in collaborative learning and develops their ability of team work.

III. Emerging technology not only improves the performance but also provide feedback and their progress with the applications to the teachers, it adjusts for student ability and prior experience.

IV. Emerging technology brings developments in secondary level students learning when the application is integrated into the typical instructional day.

V. Emerging technology also plays an important role in curriculum content. It improves performance to design and implement projects of any topic in biology it being assessed by a particular standardized test.

VI. Integration of emerging technology with education, it brings professional advancement in instructors, and use of this at home and schools modify the thinking ability of learners also that is demand of this level in school.

Different styles of delivering of information in teaching strategies it adds so many abilities of secondary level students to proceeds the information like as it develops sense of ideas and articulating learning the tools of emerging technology can bone up informative materials and its modifications in the environment of learning mostly when they are in biology classroom. In this healthy environment secondary level students can interact with different software and carry out research, develop the work ability. This development didn't limit only in school boundary but it is also the outside of this wall. In education of $2^{1 \text { st }}$ century in digital age learning the tools of emerging technology are most important not only for secondary level students but also for the instructors and the healthy environment of the school.

\section{Overall Mean Achievement Scores}

In the pre-test before the treatment of the two groups of experimental group and control group, there was not any statistically different. After the treatment to both groups' i.e. experimental group and control group the test results were significantly different in the scores. The mean score of both groups i.e. control group and experimental group were respectively 13.93 and 13.27 which was not significantly different before the treatment. On the other hand, after the treatment to both groups, control group with traditional method treatment and experimental group with emerging technologies, the result of the mean score was in control group 17.07 and in experimental group was 20.30 which was significantly different. In this study it can be suggested that at the beginning the prior levels of the knowledge of the control group and control group was equivalent. But after treatment to both groups the mean scores were significantly different. The difference in the mean score was 3.23. The score of experimental group was 3.23 score high than the score of control group mean score.

If we see the results of the data, we can also see the difference in the median and mode of the scores of both control group and experimental group. The median before the treatment was 14.00 in both control group and experimental group, but after the treatment the scores were significantly different. The median score after treatment to control group and experimental group were respectively 17.00 and 20.00. The experimental group was 3.00 score performed better than the control group.

Therefore, if we see in the table 1 the quartile of the control group and experimental group scores before the treatment was not significantly different but after treatment to the control group and experimental group the score came significantly different. The difference in the two groups control group and experimental group at $25^{\text {th }}, 50^{\text {th }}$, and $75^{\text {th }}$ percentiles were respectively $3.00,3.00$, and 3.25 . The 
experimental group performs better than the control group. Also the frequencies of Table 3 and Table 4 show that the scores before the treatment to control group and experimental group were not significantly different. But if we see on that table the scores after treatment were significantly different. The highest score of 25 numbers were taken by the control group only one time but the experimental group took six times, this shows that experimental group performed better than the control group.

The scores obtained in achievement test result analyzed independent sample t test result was also reject the null hypothesis and except alternate hypothesis that there is significant difference in the treatment given to both groups of control group and experimental group. Therefore, the results finding suggested that the students of experimental group who were given treatment through emerging technologies were better than the control group who were treated with the traditional method of teaching.

The overall performance of the experimental group on achievement test was significantly better than that of the control group. In pre test analysis, the mean of control group is 13.93 and the experimental group is 13.27, respectively. In post test analysis, the mean of control group is 17.07 and the experimental group is 20.30. In null hypothesis, $\mathrm{H}_{0} 1$, stating no significant difference between the mean achievement scores of the experimental and the control groups on achievement test was rejected. This shows that in post test the experimental group performed very well as compared to control group. This also shows that the effect of emerging technology based teaching techniques at secondary level for Biology subject is very useful in enhancing the student's achievement.

Table 4.1: $\quad$ Descriptive Statistics analysis

\begin{tabular}{|c|c|c|c|c|c|c|c|c|}
\hline \multirow[t]{3}{*}{ Statistics } & \multicolumn{4}{|c|}{ Control Group } & \multicolumn{4}{|c|}{ Experimental Group } \\
\hline & & Control & Score before & Score after & Student & Experimental & Score before & Score after \\
\hline & Student ID & Group & Treatment & Treatment & ID & Group & Treatment & Treatment \\
\hline Valid N & 30 & 30 & 30 & 30 & 30 & 30 & 30 & 30 \\
\hline Missing $N$ & 0 & 0 & 0 & 0 & 0 & 0 & 0 & 0 \\
\hline Mean & & & 13.93 & 17.07 & & & 13.27 & 20.30 \\
\hline Median & & & 14.00 & 17.00 & & & 14.00 & 20.00 \\
\hline Mode & & 2 & $12^{\mathrm{a}}$ & 17 & & 1 & 16 & $20^{\mathrm{a}}$ \\
\hline Std. Deviation & & & 3.581 & 3.759 & & & 3.667 & 3.544 \\
\hline Sum & & 30 & 418 & 512 & & 30 & 398 & 609 \\
\hline $25^{\text {th }}$ Percentile & & & 11.75 & 15.00 & & & 10.50 & 18.00 \\
\hline $50^{\text {th }}$ Percentile & & & 14.00 & 17.00 & & & 14.00 & 20.00 \\
\hline $75^{\text {th }}$ Percentile & & & 17.00 & 20.00 & & & 16.00 & 23.25 \\
\hline
\end{tabular}

a. Multiple modes exist. The smallest value is shown

Table 4.1 shows the frequencies of both experimental group and control group, both were of 30 frequency and percentage was 100.0 also valid percent was 100.0 and cumulative percent was 100.0. 
Table 4.2: $\quad$ Frequencies of experimental group and control group

\begin{tabular}{|c|c|c|c|c|c|}
\hline \multicolumn{6}{|c|}{ Control Group } \\
\hline & & Frequency & Percent & $\begin{array}{l}\text { Valid } \\
\text { Percent }\end{array}$ & $\begin{array}{c}\text { Cumulative } \\
\text { Percent }\end{array}$ \\
\hline Valid & Control Group & 30 & 100.0 & 100.0 & 100.0 \\
\hline \multicolumn{6}{|c|}{ Experimental Group } \\
\hline & & Frequency & Percent & $\begin{array}{r}\text { Valid } \\
\text { Percent }\end{array}$ & $\begin{array}{r}\text { Cumulative } \\
\text { Percent }\end{array}$ \\
\hline Valid & Experimental Group & 30 & 100.0 & 100.0 & 100.0 \\
\hline
\end{tabular}

Table 4.2 shows the score frequencies of both experimental group and control group before treatment. The lowest score frequency of control group was 8 while the lowest frequency of the control group was 7 . On the other hand, the highest frequency of both experimental and control group was 20. It shows that before treatment there was no significantly difference between the two groups' i.e. experimental group and control group.

Table 4.3: $\quad$ Score frequencies of both Experimental group and Control group before treatment

\begin{tabular}{|c|c|c|c|c|c|c|}
\hline \multicolumn{6}{|c|}{ Score before Treatment } & \multirow{3}{*}{$\begin{array}{l}\text { Table } 4.3 \text { shows } \\
\text { the score } \\
\text { freauencies }\end{array}$} \\
\hline \multicolumn{3}{|c|}{ Control Group } & \multicolumn{3}{|c|}{ Experimental Group } & \\
\hline \multicolumn{2}{|c|}{ Score } & \multirow{2}{*}{$\frac{\text { Frequency }}{3}$} & \multicolumn{2}{|c|}{ Score } & \multirow{2}{*}{$\begin{array}{c}\text { Frequency } \\
2\end{array}$} & \\
\hline Valid & 8 & & Valid & 7 & & \\
\hline & 9 & 2 & & 8 & 3 & experimental \\
\hline & 10 & 1 & & 9 & 2 & group and \\
\hline & 11 & 1 & & 11 & 3 & control group \\
\hline & 12 & 5 & & 12 & 2 & The lowest score \\
\hline & 14 & 5 & & 13 & 2 & frequency of \\
\hline & 15 & 1 & & 14 & 2 & $\begin{array}{l}\text { control group } \\
\text { was } 10 \text { while the }\end{array}$ \\
\hline & 16 & 4 & & 15 & 3 & lowest \\
\hline & 17 & 2 & & 16 & 6 & frequency of the \\
\hline & 18 & 3 & & 17 & 2 & group was 13 . \\
\hline & 19 & 2 & & 18 & 2 & On the other \\
\hline & 20 & 1 & & 20 & 1 & hand, the highest \\
\hline & Total & 30 & & Total & 30 & \\
\hline
\end{tabular}

experimental and control group was 25 , but the difference is that the Control group 25 score frequency was 1 while Experimental group 25 score frequency was 6 . It shows that after treatment there was significantly difference between the two groups' i.e. experimental group and control group. 
Table 4.4: $\quad$ Score frequencies of both Experimental group and Control group after treatment

\begin{tabular}{ccccc}
\hline \multicolumn{5}{c}{ Score After Treatment } \\
\hline & Control Group & \multicolumn{2}{c}{ Experimental Group } \\
\hline Score & Frequency & Score & Frequency \\
\hline Valid 10 & 1 & Valid & 13 & 2 \\
\hline 11 & 3 & 14 & 1 \\
14 & 2 & 16 & 2 \\
15 & 4 & 18 & 3 \\
16 & 2 & 19 & 2 \\
17 & 7 & 20 & 6 \\
18 & 1 & 21 & 4 \\
19 & 2 & 22 & 2 \\
20 & 3 & 23 & 1 \\
21 & 2 & 24 & 1 \\
23 & 1 & 25 & 6 \\
24 & 1 & & \\
25 & 1 & & 30 \\
Total & 30 & Total & \\
\hline
\end{tabular}

\subsection{T Test Results}

The test results are determined by comparing the difference between the pre-test and post-test scores. The groups T-test determine whether there is a significant difference between the two averages. This section describes the data, the results of the analysis, and the data obtained from the study in the form of an organized table. For the comparison of the experimental and control groups pre-test score, independent samples t-test results are shown in Table 4.4.

Table 4.5: Independent samples t-test results: To compare the pre-test scores of the test of both groups.

\begin{tabular}{llrrrr}
\hline & \multicolumn{6}{c}{ Group Statistics } \\
\hline Pre-Test & Experimental & N & Mean(X) & Std. Deviation(SD) & Std. Error Mean \\
Score & Group & 30 & 13.27 & 3.667 & .669 \\
& Control Group & 30 & 13.93 & 3.581 & .654 \\
\hline
\end{tabular}

The test results were analyzed using an independent sample $t$ test. $X=13.27$ was the The mean of the experimental group pre-test and $\mathrm{SD}=3.667$ was the standard. Contrarily $\mathrm{X}=13.93$ was the mean of the control group pre-test and $\mathrm{SD}=3.581$ was the standard deviation. The analysis found that there was no significant difference between the pre-test scores of the experimental and control groups. For the comparison of the experimental and control groups post-test score, independent samples t-test results are shown in Table 4.5. 
Table 4.6: Independent samples t-test results: To compare the post-test scores of both groups Group Statistics

\begin{tabular}{llrrrr}
\hline & & & \multicolumn{2}{c}{ Std. } \\
& Group & N & Mean(X) & Deviation(SD) & Std. Error Mean \\
\hline Post- & Experimental & 30 & 20.30 & 3.544 & .647 \\
Test & Group & & 17.07 & 3.759 & .686 \\
Score & Control Group & 30 & &
\end{tabular}

The test results were analyzed using an independent sample $t$ test. $X=20.30$ was the mean of the experimental group post-test and $\mathrm{SD}=3.544$ was the standard deviation, Contrarily, $\mathrm{X}=17.07$ was the mean of the control group post-test and SD $=3.759$ was the standard deviation. The analysis found that there was no significant difference between the post-test scores of both groups.

For the comparison of the experimental and control groups pre-test score and post-test score, independent samples t-test results are shown in Table 4.6.

Table 4.7: Independent samples t-test results: For the comparison of pre-Test and post-test scores of both groups

Group Statistics

Std.

\begin{tabular}{|c|c|c|c|c|c|}
\hline & Group & $\mathrm{N}$ & $\operatorname{Mean}(\mathrm{X})$ & Deviation(SD) & Std. Error Mean \\
\hline \multirow[t]{2}{*}{$\begin{array}{l}\text { Pre-test } \\
\text { Score }\end{array}$} & $\begin{array}{l}\text { Experimental } \\
\text { Group }\end{array}$ & 30 & 13.27 & 3.667 & .669 \\
\hline & Control Group & 30 & 13.93 & 3.581 & .654 \\
\hline \multirow[t]{2}{*}{$\begin{array}{l}\text { Post-test } \\
\text { Score }\end{array}$} & $\begin{array}{l}\text { Experimental } \\
\text { Group }\end{array}$ & 30 & 20.30 & 3.544 & .647 \\
\hline & Control Group & 30 & 17.07 & 3.759 & .686 \\
\hline
\end{tabular}

The test results were analyzed using an independent sample $t$ test. $X=13.27$ was the mean of the experimental group pre-test and $\mathrm{SD}=3.667$ was the standard deviation. At the same time $\mathrm{X}=13.93$ founded the mean of the control group pre-test and SD $=3.581$ the standard deviation. Contrarily, $\mathrm{X}=20.30$ was the mean of the experimental group post-test and $\mathrm{SD}=3.544$ was the standard deviation. At the same time $X=17.07$ was the mean of the control group post-test and $\mathrm{SD}=3.759$ was the standard deviation. It is founded after analysis, that there is a significant difference between the results of the mean $(\mathrm{X})$ of pre-test and post-test scores of experimental and control groups.

For the contrast of the experimental and control groups post-test score, independent samples t-test results are exposed in Table 4.7. 
Table 4.8: Independent samples t-test results: For the contrast of the experimental and control groups post-test scores

\section{Independent Samples Test}

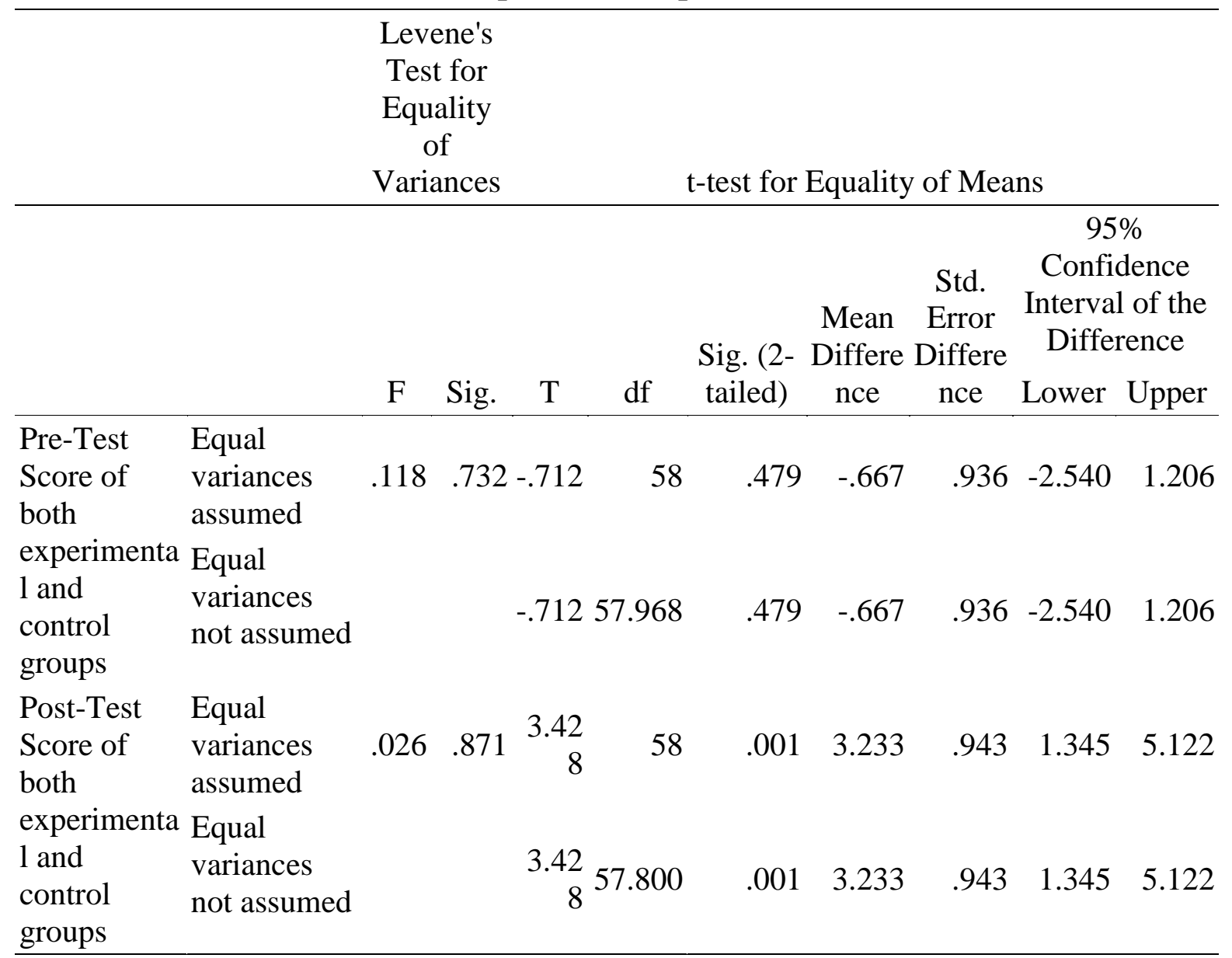

The test results were analyzed using an independent sample $t$ test. The $p$-value of pre-test .479 ( $p=-.479$; $\mathrm{p}>0.05$ ) of both experimental group and control group was greater than the p-value of 0.05 and Mean difference was .667, which shows that there was no statistically difference between the two groups before treatment. On the other hand, the $\mathrm{p}$-value of post-test $.001(\mathrm{p}=.001 ; \mathrm{p}<0.05)$ of both experimental group and control group was smaller than the p-value of 0.05 and Mean difference was .3.233, which shows that there was a statistically difference between the two groups after treatment. There the null hypothesis was rejected and alternate hypothesis was accepted.

The above results are statistically significant. Thus, it can be deduced that the use of computer assisted web 2.0 instructional technology enhanced the performance of secondary school students.

\section{Conclusions}

After analysis of the data, following conclusions were drawn:

1 The achievement between the pre experimental is greater than control pre test.

2 It is founded that major dissimilarity among the students of experimental post and control post. The mean score of experimental post students is greater than control post.

3 The difference of achievement between the students of experimental pre, experimental post and control pre, control post shows that the mean of experimental post students is greater than the control post, and control post is greater than control pre.

4 Encouraging of individual learning and successful and well-organized learning is possible Only by Emerging technology.

5 The use of evolving technologies has increased the ability of students to work and the expertise of educator. 
6 The use of emerging technologies has proven valuable, aroused curiosity and enthusiasm in students.

7

\section{Recommendations}

Experimentation with emerging technology based instruction and findings of the study led the researcher to make the subsequent recommendations.

1. Teachers may be use emerging technology based teaching aids like simulations, computer animations etc. to develop students interest in the subject for maximum teaching learning out comes.

2. To get the most output of emerging technologies, students can be given orientation training chances to expand skills in the effective use of these technologies.

3. Potential of emerging technology based instruction may be utilized to enhance quality of education at school level.

4. Teacher education institutions may start new programs to produce emerging technology programmers, engineers and analysts equipped with pedagogic skills.

\section{References}

Attewell, P. (2001). Comment: The First and Second Digital Divides. Sociology of Education. 74' Boss, S. \& Krauss, J. (2007). Real Projects in a Digital World. Principal Leadership. 8 (4): 22-26.

CEO Forum on Education and Technology (2001). Education Technology Must Be Included in Comprehensive Education Legislation. 3-11. www.ceoforum.org

Cynthia, R. (2228). Implementing Educational Technology in Higher Education: A Strategic Approach, Purdue University North Central. DOI: 10.9743/JEO.2008.1.1

Emma, Di Iorio (2010). Student-Centered Learning SCL Toolkit. Norway: The European Students' Union: Milica Popovic, Education International. University of Oslo.

Grace, E.S. (2007). Differentiating instruction with technology in K-5 Classroom. International Society for Technology in Education. ISBN 156484339.

Iqbal, A. (2002) Analysis of the Problems of Primary Education System in Pakistan: Critical Review of Literature. Malakand: Department of Management Studies, University of Malakand.

Karehka, R. (2012) Technology And Society: Impact Of Technology On Society. Retrieved Nov,08,2016 from, https://www.useoftechnology.com/technology-society-impact-technology-society/

Kulik, J. (2009) Effects of Using Instructional Technology in Elementary and Secondary Schools: What Controlled Evaluation Studies Say. SRI International.

Lanius, C. (2004) PowerPoint, Not Your Grandmother's Presentations, but is it Evil? Cell Biology Education, Fall 2004.

Machemer, P. L., \& Crawford, P. (2007). Student perceptions of active learning in a large crossdisciplinary classroom. Active Learning in Higher Education, 8(1), 9-30. DOI: 10.1177/1469787407074008.

Macllan, E. \& Soden, R. (2004). The importance of epistemic cognition in student-centred learning: Instructional Science, Vol. 32, No. 3, 02.11.2004, p. 253-268.

Mangal, S. K. (2005). Advanced Educational Psychology. New Delhi, Prentice Hall of India. Pvt. Limited.

Margaret, H., Katherine, M.C., \& Fred, C. (2000) Perspectives on Technology and Education Research: Lessons from the Past and Present. The Secretary's Conference on Educational Technology.

Ringstaff \& Kelley (2002), Getting the Most of Technology in Schools. Knowledge Brief, Retrieve fromhttps://www.researchgate.net/publication/234744923_Getting_the_Most_from_Technology_in_Scho ols_Knowledge_Brief

Roschelle, J.M., Pea, R.D., Hoadley, C.M., Gordin, D.N. \& Means, B.M. (2000) Changing How and What Children Learn in School with Computer-Based Technologies. The Future of Children, 10:2, 76101. 
Ryan, E.D. (2010). The use of instructional technology in the classroom: selection and effectiveness. New York: United States Military Academy, West Point.

Sackville, A. (2003). The emperor's new clothes: Navigating Innovations in Teaching and Learning, British Journal of Sociology of Education.

Swain, P. (2003). Educators and Technology Standards: Influencing the Digital Divide, Journal of Research on Technology in Education, v34 n3

Uzma, A. (2014). Application of Educational Technology in Instructional Material for Distance Education in UK, Pakistan and Thailand. Journal of Education \& Research and Education center. Allama Iqbal Open University, Islamabad. Pakistan. XXII(I).

Van, E. et. al (2005), Fostering Reflective Teaching Practice in Pre-Service Education. Retrieve from: https://books.google.com.pk/books?id=dBgxDwAAQBAJ\&pg=PA158\&lpg=PA158\&dq=van+Eekelen+e $\mathrm{t}+\mathrm{al}+$ research+on+technology+2005\&source=bl\&ots=xWAiO0vHbF\&sig=VeMkkmZnRF6jb3ztoeSMfX c9nlg\&hl=en\&sa=X\&ved=0ahUKEwik8PulsZjYAhXFxqQKHaQOCG0Q6AEIOjAD\#v=onepage\&q=va n\%20Eekelen\%20et\%20al\%20research\%20on\%20technology\%202005\&f=false

Web-based Education Commission (2000). The Power of the Internet for Learning: Moving from Promise to Practice. 1-84;

Yun-Jo An, Bosede Aworuwa (2010). Teaching with Web 2.0 Technologies: Benefits, Barriers and Best Practices. College of Liberal Arts and Education Texas A\&M University-Texarkana. 